\title{
Strength and microstructure of micro ceramic dust admixed lime stabilized soil
}

\author{
Resistencia y microestructura del polvo micro cerámica mezclado suelo cal estabilizado
}

\author{
Jijo James (Main and Corresponding Author) \\ Tagore Engineering College \\ Rathinamangalam, Melakottaiyur P.O., Chennai - 600127 (India) \\ jijo_blitz@yahoo.co.in
}

\author{
Pitchai Kasinatha Pandian \\ Karpaga Vinayaga College of Engineering and Technology \\ Chinnakolambakkam, Padalam, Kanchipuram - 603308 (India) \\ pknp2020@gmail.com
}

Manuscript Code: 592

Date of Acceptance/Reception: 28.02.2018/02.06.2016

DOI: $10.7764 /$ RDLC.17.1.5

\begin{abstract}
The use of micro ceramic dust (CD) as an additive to lime in soil stabilization has been analysed in this study. CD was obtained by crushing and sieving of waste ceramic tiles from construction debris. The initial consumption of lime (ICL) for soil modification was determined using Eades and Grim pH test. In order to study the effect of lime content on soil stabilization, three different lime contents (below ICL, ICL and above ICL) were used for stabilizing the soil. These three lime contents were amended with various amounts of CD to study its effect on the strength of the stabilized soil. Unconfined compression strength (UCS) tests were carried out on the stabilized soil specimens of dimensions $38 \mathrm{~mm} \times 76 \mathrm{~mm}$ at different ages of curing. The spent UCS samples were crushed and sieved to carry out Atterberg limits and free swell tests followed by $x$-ray diffraction (XRD) and scanning electron microscopy (SEM) tests for determining changes in microstructure. The results indicated that the addition of CD resulted in a marginally negative influence on the early strength of the stabilized soil at three days of curing whereas it enhanced the delayed strength of the soil at 28 days of curing, gaining between $12-14 \%$ strength. The effect of CD on the plasticity and swell-shrink of lime stabilized soil indicated a further reduction in plasticity and swell-shrink nature. The mineralogy of the amended soil revealed the formation of CSH and CAH minerals responsible for strength gain. SEM images used to analyse the microstructure of the virgin and stabilized soil, indicated the formation of a dense and compact microstructure. Finally, it was concluded that CD can be adopted as an auxiliary additive to lime in stabilization of expansive soil with provision of sufficient curing and the delayed onset of early strength due to CD can be overcome by using higher lime content in stabilization.
\end{abstract}

Key words: Expansive soil, lime stabilization, ceramic dust, strength, mineralogy, microstructure

Resumen

El uso de polvo de cerámica micro (CD) como un aditivo a la cal en la estabilización del suelo se ha analizado en este estudio. El CD se obtuvo triturando y tamizando las baldosas cerámicas de desecho de los desechos de la construcción. El consumo inicial de cal (ICL) para la modificación del suelo se determinó usando Eades y Grim pH test. Con el fin de estudiar el efecto del contenido de cal sobre la estabilización del suelo, se utilizaron tres contenidos diferentes de cal (por debajo de ICL, ICL y superior ICL) para estabilizar el suelo. Estos tres contenidos de cal fueron modificados con varias cantidades de CD para estudiar su efecto sobre la resistencia del suelo estabilizado. Se realizaron pruebas de resistencia a la compresión no confinada (UCS) en las muestras de suelo estabilizado de dimensiones $38 \mathrm{~mm} \times 76 \mathrm{~mm}$ a diferentes edades de curado. Las muestras de UCS gastadas se trituraron y se tamizaron para llevar a cabo los límites de Atterberg y las pruebas de hinchamiento libre seguidas por difracción de rayos X (XRD) y microscopía electrónica de barrido (SEM) para determinar los cambios en la microestructura. Los resultados indicaron que la adición de CD resultó en una influencia marginalmente negativa sobre la resistencia inicial del suelo estabilizado a los tres días de curado, mientras que mejoró la resistencia tardía del suelo a los 28 días de curado, ganando entre el 12-14\% de resistencia. El efecto del CD sobre la plasticidad y contracción por hinchamiento del suelo estabilizado con cal indicó una reducción adicional en la plasticidad y la naturaleza de contracción por hinchamiento. La mineralogía del suelo modificado reveló la formación de minerales CSH y CAH responsables de la ganancia de fuerza. Las imágenes SEM utilizadas para analizar la microestructura del suelo virgen y estabilizado, indicaron la formación de una microestructura compacta y densa. Finalmente, se concluyó que el CD puede ser adoptado como un aditivo auxiliar para la cal en la estabilización del suelo expansivo con provisión de suficiente curado y el inicio retrasado de la resistencia temprana debido al CD puede superarse usando un mayor contenido de cal en la estabilización.

Palabras clave: Suelo expansivo, estabilización de cal, polvo de cerámica, resistencia, mineralogía, microestructura

Introduction

Expansive soils have the tendency to undergo volume change behaviour and cause large uplift pressures and upheaval of structures built on them (Bhuvaneshwari, Robinson, \& Gandhi, 2013). The enormous volume change is due to the presence of montmorillonite group of minerals (Sridharan \& Prakash, 2000). They are characterized by high cation exchange capacity (Celik \& Nalbantoglu, 2013), small particle size (Fityus \& Buzzi, 2009) and large specific area (Nalbantoğlu, 2004). This volume change behaviour of expansive soils results in damage to structures constructed on 
them (Al-Mukhtar, Lasledj, \& Alcover, 2010b; Al-Rawas, Taha, Nelson, Al- Shab, \& Al-Siyabi, 2002; Bhuvaneshwari et al., 2013; Celik \& Nalbantoglu, 2013). Such soils need to be stabilized to improve their properties for safe and stable construction on them. Lime stabilization has been the most widely used method for stabilization of expansive soils (AlMukhtar, Khattab, \& Alcover, 2012; Bhuvaneshwari et al., 2013; Thyagaraj, Rao, Sai Suresh, \& Salini, 2012). Stabilizing expansive soil by the addition of lime is an ancient art and an age-old practice, which has been followed all over the world. Lime is an effective stabilizing agent for soft and expansive soils and can enormously increase the workability and strength while limiting volume changes (Bhuvaneshwari et al., 2013).

Lime stabilization has been studied by researchers extensively. Lime is a broad term that is used to refer to the following three types: quicklime $(\mathrm{CaO})$, slaked or hydrated lime $\left(\mathrm{Ca}(\mathrm{OH})_{2}\right)$ and carbonate lime $\left(\mathrm{CaCO}_{3}\right)$ (Transport Research Laboratory, 2003). Quicklime and hydrated lime are widely used as stabilizers (Bhuvaneshwari et al., 2013). The addition of quick lime or hydrated lime to clay results in reactions taking place in two stages namely immediate reactions and long-term reactions. The immediate reactions include ion exchange and flocculation and long term or slow reactions include solidification by pozzolanic reactions (Bell, 1996; Bhuvaneshwari et al., 2013; Mishra, 2012). Carbonate lime is usually not adopted in soil stabilization because carbonate lime is a stable compound and remains inert in the presence of water. However, addition of carbonate lime can bring about improvement in soil properties. James \& Pandian (2013) had found that the addition of egg shell powder whose major composition is calcium carbonate, improved the strength of the soil by means of physical interaction. Lime was adopted as the primary stabilizer for the soil under consideration because all types of clay minerals react with lime (Bell, 1996). Moreover, the effectiveness of cement stabilization becomes marginal when plasticity index of the soil is more than $20 \%$ (Transport Research Laboratory, 2003). Several researchers have worked on the studying the effects of lime on soil properties including strength and modulus (Bell, 1996; Garzón, Cano, O`Kelly, \& Sánchez-Soto, 2016), mineralogy and microstructure (Aldaood, Bouasker, \& Al-Mukhtar, 2014b; Rajasekaran, Murali, \& Srinivasaraghavan, 1997; Rajasekaran \& Rao, 1997), permeability and compressibility (Rajasekaran \& Rao, 2002a, 2002b) and swell control (Aldaood, Bouasker, \& Al-Mukhtar, 2014a; Seco, Ramírez, Miqueleiz, \& García, 2011). Others have worked on the various parameters that influenced lime stabilization of soils including curing conditions (Al-Mukhtar, Lasledj, \& Alcover, 2010a; Al-Mukhtar et al., 2010b; Aldaood et al., 2014b; George, Ponniah, \& Little, 1992; Nasrizar, Muttharam, \& Illamparuthi, 2010b), placement water content (Nasrizar, Muttharam, \& Illamparuthi, 2010a), pulverization quality of soil (Bozbey \& Garaisayev, 2010), strain rates (Alzubaidi \& Lafta, 2013) and extreme soil and weathering conditions (Aldaood, Bouasker, \& Al-Mukhtar, 2014c, 2014d; Kinuthia, Wild, \& Jones, 1999; Rajasekaran, 2005; Stoltz, Cuisinier, \& Masrouri, 2014).

\section{State of the Art}

With industrialization and generation of huge quantities of industrial by-products, researchers have tried to adopt industrial wastes as a chemical additive for soil stabilization. Sewage sludge ash, Silica fume, Sugarcane bagasse ash, Groundnut shell ash, Marble dust, Rice husk ash, Rice straw ash, Locust bean waste ash, Egg shell ash, Cement kiln dust, Lime kiln dust, Sawdust ash, Waste paper sludge ash, Incineration ash, Limestone dust, Cement by-pass dust, Wood ash, Bottom ash, Calcined paper sludge, Palm oil fuel ash, Pumice waste, Lime sludge, Construction and demolition waste, Quarry dust and Crushed glass are some of the wastes that have been adopted successfully in soil improvement applications (Dahale, Nagarnaik, \& Gajbhiye, 2012; James \& Pandian, 2015, 2016b; Sabat \& Pati, 2014). A lot of researchers have also applied solid wastes in combination with cement/lime in stabilization of soils. With so much research in utilization of solid wastes in soil stabilization, it has been firmly established that solid wastes can further augment the stabilization potential of cement and lime (James \& Pandian, 2016a). One such solid waste material that is generated in huge quantities is construction and demolition wastes. The construction and demolition waste generated in India in the year 2013 alone was 530 million metric ton (Centre for Science and Environment, 2014). Several efforts have been undertaken in the past in managing this waste. Reutilization of this waste is an active way for effective management. But, it is one waste material whose composition varies widely depending upon the source. Adopting such a waste material with a varying composition poses a problem of unpredictability when reused in construction related activities. Hence, a better option would be to segregate the waste and use it based on type. One such demolition waste component is ceramic wastes. Ceramic materials are inorganic non-metallic materials made from a mixture of clay, various elements, powders and water. In construction industry, it is most commonly encountered in the form of bricks, tiles, plates, glass and sanitary ware to name a few. Ceramic wastes mainly originate from the construction industry. Ceramic materials represent around $45 \%$ of construction and demolition waste, and originate not only from the building process, but also as rejected bricks and tiles from industry (Reig, Tashima, Soriano, Borrachero, Monzó, et al., 2013). The global production of ceramic tiles is around 8500 million square meters (Tavakoli, Heidari, \& Karimian, 2013). The annual ceramics production in India is around 100 million tons worth $₹ 18,000$ crores with an approximate production of 600 million square meters (Anwar, Ahmad, Mohammed, Husain, \& Ahmad, 2015; Raval, Patel, \& Pitroda, 2013). About 15 to $30 \%$ of the waste is generated from the bricks and tile industry. Sağın, Böke, Aras, \& Yalçın (2012) state that ceramic materials like crushed tiles are artificial pozzolans. The specific gravity of ceramic wastes has been reported in 
the range of 2.27 to 2.82 by various investigators (Kamala \& Rao, 2012; Sabat, 2012; Sekar, Ganesan, \& Nampoothiri, 2011; Tavakoli et al., 2013; Veera Reddy, 2010). Ceramic wastes can also be employed as supplementary cementitious materials (Reig, Tashima, Soriano, Borrachero, Monzó et al., 2013). The utilization of ceramic waste along with cement in concrete and blocks is well documented (Halicka, Ogrodnik, \& Zegardlo, 2013; Pacheco-Torgal \& Jalali, 2010; Silva, De Brito, \& Veiga, 2008; Tavakoli et al., 2013; Veera Reddy, 2010; Wattanasiriwech, Saiton, \& Wattanasiriwech, 2009). The formulation and use of lime mortars with ceramic particles has, in the past, been a very common technique (Matias, Faria, \& Torres, 2014b). The utilization of ceramics with lime in mortar has also been probed by researchers (Bakolas, Aggelakopoulou, \& Moropoulou, 2008; Matias, Faria, \& Torres, 2014a; Matias et al., 2014b; Moropoulou, Bakolas, Moundoulas, Aggelakopoulou, \& Anagnostopoulou, 2005). Despite, its pozzolanic property being well known and widely researched in other areas of Civil Engineering, its reuse as a pozzolan in the avenue of soil stabilization has been rather limited. Several earlier work involving the use of waste ceramic dust (CD) from tiles have been reported (Ameta, Wayal, \& Hiranandani, 2013; Chen \& Idusuyi, 2015; Geeta Rani, Shivanarayana, Prasad, \& Prasada Raju, 2014; Kumar, Sharma, \& Singh, 2014; Prasad, Prasad, \& Babu, 2015; Sabat, 2012; Singh, Kumar, \& Sharma, 2014; Summayya, Rafeequedheen, Sameer, Khais, \& Jithin, 2016). However, even these works involved the utilization of CD only as a standalone stabilizer. Moreover, most of the aforementioned authors considered ceramic waste improved the behaviour of clay due to physical interaction by replacement of clay particles with coarser $C D$ particles. This may be due to the coarse nature of the $C D$ adopted in the various investigations. And as a possible consequence, none of them included any investigation on the inherent mineralogical or microstructural changes taking place in the stabilized soil due to the addition of $C D$ in their researches. Investigations involving the use of $C D$ as a pozzolan with lime/cement are virtually absent. The available earlier work involving the use of CD as auxiliary additive to lime-flyash (Sabat \& Bose, 2014) and cement (James \& Pandian, 2014a) showed promising results. However, even in those works, no detailed investigations as to the mineralogical changes were undertaken.

\section{Description of the Problem}

Expansive soils have posed severe problems for geotechnical engineers worldwide. They need to be stabilized for reducing the distressing effects on structures built on them. Lime stabilization has been the most common technique adopted in stabilizing expansive soils. However, utilization of solid wastes in soil stabilization has gained prominence in recent times. This study focuses on the use of one such solid waste, $C D$ along with lime in soil stabilization. Based on the state of the art, it can be seen that there still is a need for investigations wherein the performance of CD in combination with lime/cement in soil stabilization along with mineralogical and microstructural investigations as support. This work attempts to address this need by investigating the performance of $C D$ as an auxiliary additive to lime in stabilization of an expansive soil along with mineralogical and microstructural studies to understand the changes taking place at the micro level. Thus, the primary objective of this work was to study the effect of CD on the strength, index properties like plasticity and swell-shrink and microstructural characteristics including mineralogy, of a lime stabilized expansive soil.

Materials and Their Properties

The materials used in this study include the soil to be stabilized, lime, the primary stabilizer and CD used as an admixture.

\section{Natural Soil}

The soil used for the study was obtained from Thatthamanji Village in Thiruvallur District of Tamil Nadu, India. The soil was black in colour and had very high initial moisture content when it was excavated from the ground. The soil was very fine and sticky when rubbed between fingers. The properties of the soil were tested in the laboratory and the results are summarized in Table 1.

According to Bureau of Indian Standards (BIS, 1970), based on the liquid limit and free swell index, the soil's degree of expansion and severity can be classified. Based on the properties of the soil under investigation, the soil is classified as having high degree of expansion and critical severity. The soil sample was subjected to X-ray fluorescence (XRF) for determination of its chemical composition and X-ray diffraction (XRD) to determine its mineralogy. The morphology of the materials used in the study was investigated using scanning electron microscopy (SEM). Figure 1 shows the SEM image of soil, lime and CD at a magnification of 1000x. The micrographs reveal that soil particles are aggregated into lumps due to the cohesive nature of the clayey soil. However, it also shows the platy clay particles that make up the soil aggregates. The mineralogy of materials used in this investigation is shown in Figure 2. The mineralogy of the soil under investigation revealed the presence of montmorillonite and quartz minerals. The chemical composition of soil is tabulated in Table 2. The test revealed that silica and alumina were the major components of the soil adopted in the study. 


\begin{tabular}{ll}
\multicolumn{2}{c}{ Table 1. Properties of Soil. (Self-Elaboration). } \\
\hline Property & Value \\
\hline Liquid Limit & $68 \%$ \\
Plastic Limit & $27 \%$ \\
Plasticity Index & $41 \%$ \\
Shrinkage Limit & $10 \%$ \\
Specific Gravity & 2.76 \\
\%Gravel & 0 \\
\%Sand & 2.5 \\
\%Silt & 60.5 \\
\%Clay & 37 \\
Maximum Dry Density & $15.3 \mathrm{kN} / \mathrm{m}^{3}$ \\
Optimum Moisture Content & $25 \%$ \\
UCS & $115.8 \mathrm{kPa}$ \\
Free Swell Index & $98 \%$ \\
pH & 6.53 \\
Soil Classification & $\mathrm{CH}$ \\
Degree of Expansion & High \\
Severity & Critical \\
\hline
\end{tabular}

\section{Lime}

The lime adopted for the study was laboratory grade hydrated lime with $95 \%$ purity sourced from Nice Chemicals, India. Laboratory grade lime offered better control over the test results because of the consistency in its composition, which was the primary reason behind adopting laboratory grade lime rather than commercially available lime for this study. Lime was also subjected to XRF and XRD for determination of its chemical composition and mineralogy respectively. The mineralogy of lime indicated the presence of calcium hydroxide and calcium carbonate. A comparison of the particle size with other materials adopted in this investigation reveals that lime particles are finer in size. Soil particles in the image are actually flocs of clay platelets which result in a larger particle size.

\section{Ceramic Dust}

$C D$ is a waste powder from ceramic bricks, roof and floor tiles and stoneware industries. White paste ceramic tiles were adopted in the current study. CD adopted in the present study had $97.4 \%$ silt size fractions and $2.6 \%$ clay size fractions. The specific gravity of the CD adopted in the study came out to be 2.55. From the SEM image (Figure 1), it can be seen that $\mathrm{CD}$ adopted in this study has a rough surface texture and the individual particles are angular in nature. The particle sizes in the field of view vary, with sizes ranging from very small to large particles. The chemical composition of the CD revealed that it is also rich in silica and alumina making it a good pozzolan. The mineralogy of CD revealed that quartz was the major mineral present in it. Calcite and dolomite were also noticed among others.

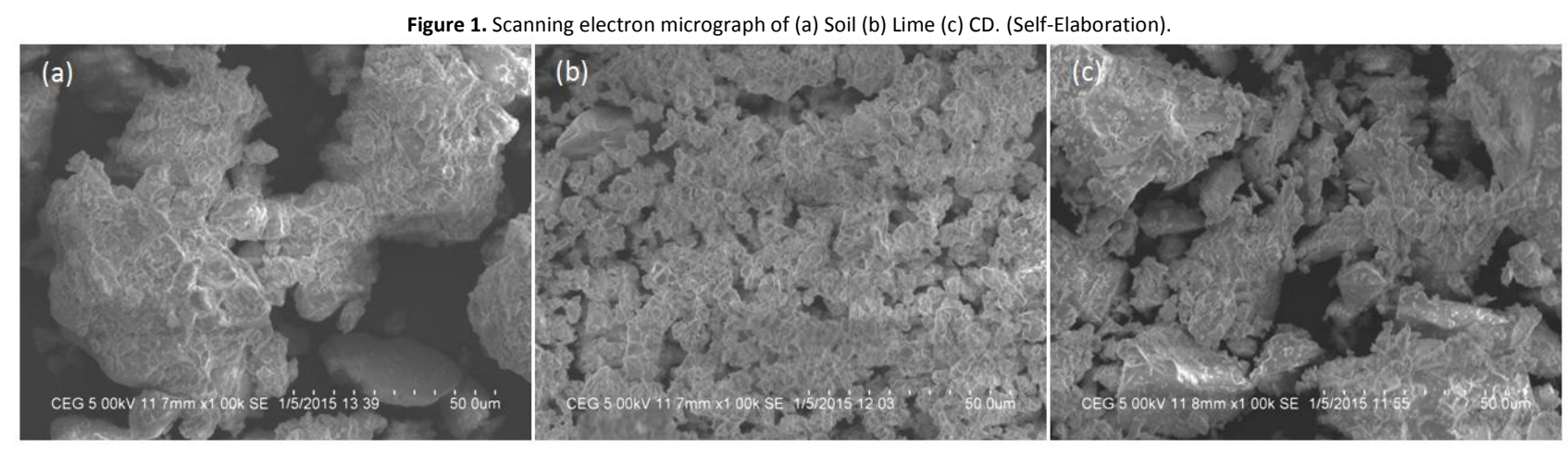



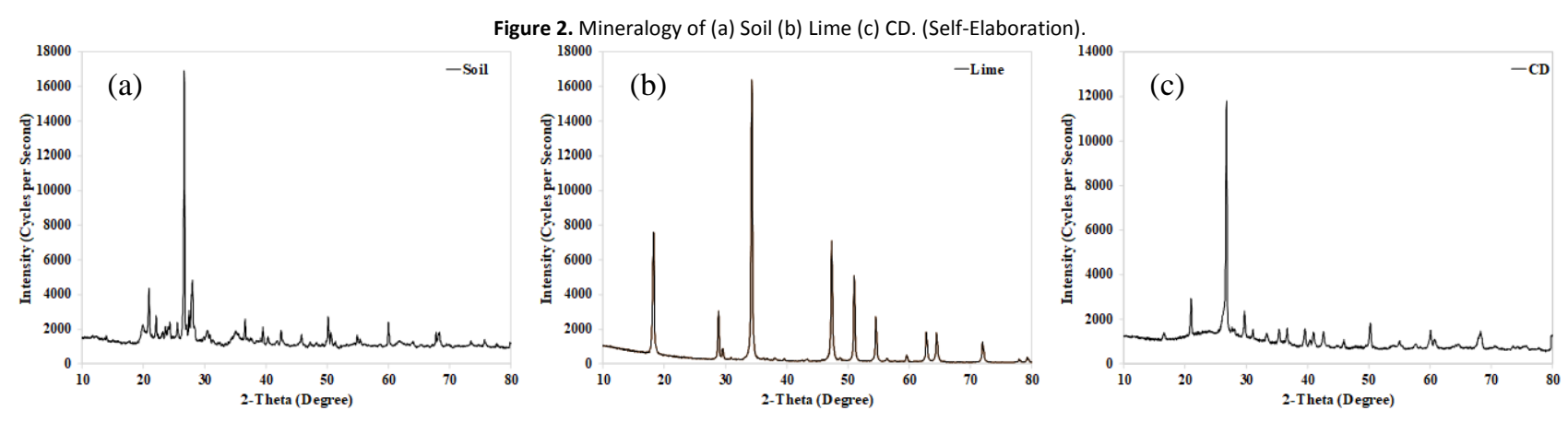

\begin{tabular}{lllllllllllll}
\hline \multicolumn{10}{c}{ Table 2. Chemical composition of materials (Self-Elaboration). } \\
\hline (\%) & $\mathrm{SiO}_{2}$ & $\mathrm{Al}_{2} \mathrm{O}_{3}$ & $\mathrm{CaO}$ & $\mathrm{Fe}_{2} \mathrm{O}_{3}$ & $\mathrm{~K}_{2} \mathrm{O}$ & $\mathrm{MgO}$ & $\mathrm{MnO}$ & $\mathrm{Na}_{2} \mathrm{O}$ & $\mathrm{P}_{2} \mathrm{O}_{5}$ & $\mathrm{TiO}_{2}$ & $\mathrm{SO}_{3}$ \\
\hline Soil & 63.62 & 18.82 & 2.30 & 7.48 & 2.29 & 1.74 & 0.04 & 1.42 & 0.04 & 0.88 & 0.20 \\
Lime & 0.25 & 0.05 & 72.77 & 0.04 & 0.003 & 14.60 & 0.004 & 0.05 & 0.005 & 0.003 & 0.05 \\
CD & 57.14 & 25.24 & 1.88 & 6.53 & 3.89 & 1.11 & 0.02 & 1.81 & 0.11 & 0.68 & 0.01 \\
\hline
\end{tabular}

The methodology of the investigation involved the following stages: Preparation of materials, Characterization of materials, Determination of lime dosage, Selection of additive dosage, Experimental investigation and Microstructural Investigation including mineralogy.

\section{Preparation of materials}

The soil sample was prepared in accordance with the procedure stipulated in BIS code (BIS, 1983). Lime used in the laboratory was used as available from the manufacturer without any preparatory techniques. CD is not a readily available form of the waste material. Broken ceramic tiles were carefully segregated from construction debris from a demolition site, free from cement mortar. The segregated ceramic tiles were then crushed and ground to a powder using abrasion testing machine. It was then sieved through BIS $75 \mu$ sieve and the fine micro fractions were stored in airtight plastic containers for use in the study.

\section{Characterization of materials}

The soil was tested for its properties including liquid and plastic limit (BIS, 1985b), shrinkage limit (BIS, 1972), specific gravity (BIS, 1980b), grain size distribution (BIS, 1985a), compaction characteristics (BIS, 1980a), UCS (BIS, 1991), Free swell index (BIS, 1977) and $\mathrm{pH}(\mathrm{BIS}, 1987)$ in accordance with various codes of BIS. It was then classified as per BIS soil classification system (BIS, 1970) (Table 1). CD was subjected to specific gravity test (BIS, 1980b) and grain size distribution test (BIS, 1985a) in accordance with BIS codes. Soil, lime and CD were subjected to XRF testing for determination of their chemical composition. The mineralogy of the materials was determined by using XRD. The microstructure of the three materials was studied using SEM.

\section{Determination of lime dosage}

The lime content required for stabilization was fixed using established methods of identification. Nasrizar, Ilamparuthi, \& Muttharam (2012) state that there are three phases in the relationship between strength and lime content, first phase for lime content less than Initial Consumption of Lime (ICL), second phase for lime content above ICL but less than Optimum Lime Content (OLC) and third phase, lime content above OLC. Hence, the ICL and OLC of the soil was determined and adopted for stabilization of the soil. ICL was determined from the Eades and Grim pH Test (Eades \& Grim, 1966) as given by (ASTM, 2006). The OLC was arrived at by conducting UCS test in accordance with (BIS, 1991), on soil samples with increasing lime content and cured for a period of 2 days based on earlier works (Sivapullaiah, Katageri, \& Herkal, 2007; Thompson, 1967). The lime content of the stabilized soil specimens at which the maximum UCS was achieved was taken as the OLC. The above methodology is based on similar earlier work (James \& Pandian, $2014 \mathrm{~b}$ ). 


\section{Fixing of additive dosage}

After the fixing of lime contents for the stabilization of soil, the additive dosages were selected for the investigation. Conventionally, the content of the stabilizers, especially waste materials that are adopted in soil stabilization, are fixed at random and are reworked in subsequent investigations by the same or different investigators. A look at the literature reveals that solid wastes have been adopted in trial percentages by a majority of the researchers to study its effectiveness in soil stabilization. Similarly, in this investigation as well, the content of waste materials used as additives were selected at random. This investigation limited itself to the effect of additives at low levels of addition. Four trial dosages of $0.25,0.5,1$ and $2 \mathrm{wt}$. \% were adopted in this investigation.

\section{Experimental Investigation}

The experimental investigation involved preparation of UCS specimens of dimensions $38 \mathrm{~mm} \times 76 \mathrm{~mm}$ statically compacted to a density of $14.72 \mathrm{kN} / \mathrm{m}^{3}$, at a moisture content of $25 \%$. The samples were prepared by manually dry mixing the soil with lime and CD at calculated weights followed by addition of water to prepare a wet mix. This wet mix was packed in layers into the mould and statically compacted to prepare the UCS specimen. The prepared UCS samples were air cured for periods of 2 hours, 3, 7, 14 and 28 days in air tight sealed polythene covers to prevent loss of moisture. At the end of the specified curing periods, the samples were loaded in an electrically operated, $50 \mathrm{kN}$ capacity loading frame with three strain rates. The samples were axially loaded till failure at a strain rate of $0.625 \mathrm{~mm} / \mathrm{minute}$ to determine the UCS of the specimens. Three specimens were prepared for testing of each combination. A total of 225 UCS specimens were prepared for evaluating the strength of lime and lime-CD stabilized expansive soil not including repeat tests for confirmation of outliers in test results. The failed UCS samples were crushed, pulverized and sieved through BIS $425 \mu$ sieve for performing the Atterberg limit tests and free swell tests. These index tests were limited to only the control lime contents and the combination which produced the maximum strength (optimal combination) in order to study the effect of CD on the plasticity and swell-shrink characteristics. Three tests were performed for each of the property and the average was reported as the result. The spent UCS samples have been adopted for investigation of plasticity and swell-shrink nature in earlier investigations as well (James \& Pandian, 2016b).

\section{Microstructural Investigation}

The failed UCS specimens of the combination that produced the maximum strength were adopted for microstructural analysis. Chunks of UCS specimens of lateral dimension less than $10 \mathrm{~mm}$ with exposed failure surface were used for studying the microstructure using SEM. After separating samples for SEM, the rest of the failed specimens were crushed, pulverized and sieved through BIS $75 \mu$ sieve to be sent for analysing the mineralogy using XRD. SEM was performed at an applied voltage of $5 \mathrm{kV}$ and a working distance of $11.7 \mathrm{~mm}$. X-rays of wavelength of $1.54 \AA$ was adopted with continuous mode Gonio scan between 2-theta positions of $10^{\circ}$ and $90^{\circ}$ with a scan step of $0.02^{\circ}$ and scan speed of 25 degrees/minute. A current of $10 \mathrm{~mA}$ and voltage of $30 \mathrm{kV}$ was set in the generator.

\section{Results and Discussion}

According to ASTM (2006), the lowest percentage of lime in soil that is required to raise the $\mathrm{pH}$ of soil to 12.4 is the approximate quantum of lime required for soil stabilization. Bell (1996) and Kinuthia et al. (1999) state that normally this value is between 1 to $3 \%$. However, several researchers have reported values that are outside this range. Some of the values reported include 4\% (Al-Mukhtar et al., 2010b; Bhuvaneshwari et al., 2013; Bhuvaneswari, Thyagaraj, Robinson, \& Gandhi, 2010; Mavroulidou, Zhang, Gunn, \& Cabarkapa, 2013), 5\% (Eisazadeh, Kassim, \& Nur, 2011a; Far, Kassim, Eisazadeh, \& Khari, 2013), 6\% (Kinuthia et al., 1999), 7\% (Eisazadeh, Kassim, \& Nur, 2011b), and 7.3\% (Calik \& Sadoglu, 2013). In the present study, the ICL for the soil under investigation came out to be $5.5 \%$. The OLC was determined to be $7 \%$. It is well documented in literature that lime content more than ICL is added for pozzolanic reactions resulting in strength gain (Bhuvaneshwari et al., 2013; Kinuthia et al., 1999; Nasrizar et al., 2010b). In order to study the effect of lime stabilization below ICL, a random value of $3 \%$ lime was adopted for stabilization.

\section{Effect of lime on expansive soil}

The addition of lime results in the modification of soil properties and gain in strength. However, the extent of modification depends on the lime content. 


\section{Effect of lime content on stress-strain behaviour}

Figure 3 shows the stress strain curves of virgin as well as soil stabilized with varying percentages of lime after 28 days of curing. The stress strain curve for soil is a flat curve without any clear peak stress indicating that the soil specimen underwent plastic failure. With the addition of lime to soil, there is a development of a clear peak at higher axial stress in the stress strain curves of the stabilized soil which is an indication of the increase in strength of the stabilized soil. It can be seen that at $5.5 \mathrm{wt}$. \% and $7 \mathrm{wt}$. \% lime stabilizations, the peak stress is attained at a lower strain when compared to $3 \mathrm{wt}$. \% lime stabilization of soil. As a result, there is shift in the peak towards the left indicating an increase in the rigidity of the specimens. Comparing $5.5 \mathrm{wt}$. \% and $7 \mathrm{wt}$. \% lime stabilizations, the strain at peak strength is more or less the same, but the strength achieved is higher in the latter case. In addition, the stress strain curve for 7 wt. \% lime stabilization lies to the left of the corresponding curve for $5.5 \mathrm{wt}$. \% lime stabilization owing to comparatively quicker increase in stiffness. Thus, addition of lime to soil not only increases its strength but also reduces its plastic nature and increases its stiffness. Similar trends in stress strain curves can be seen in the investigations of earlier researchers (Kavak, Bilgen, \& Faruk Capar, 2011; Muhmed \& Wanatowski, 2013; Sharma, Phanikumar, \& Rao, 2008; Yıldız \& Soğancı, 2012).

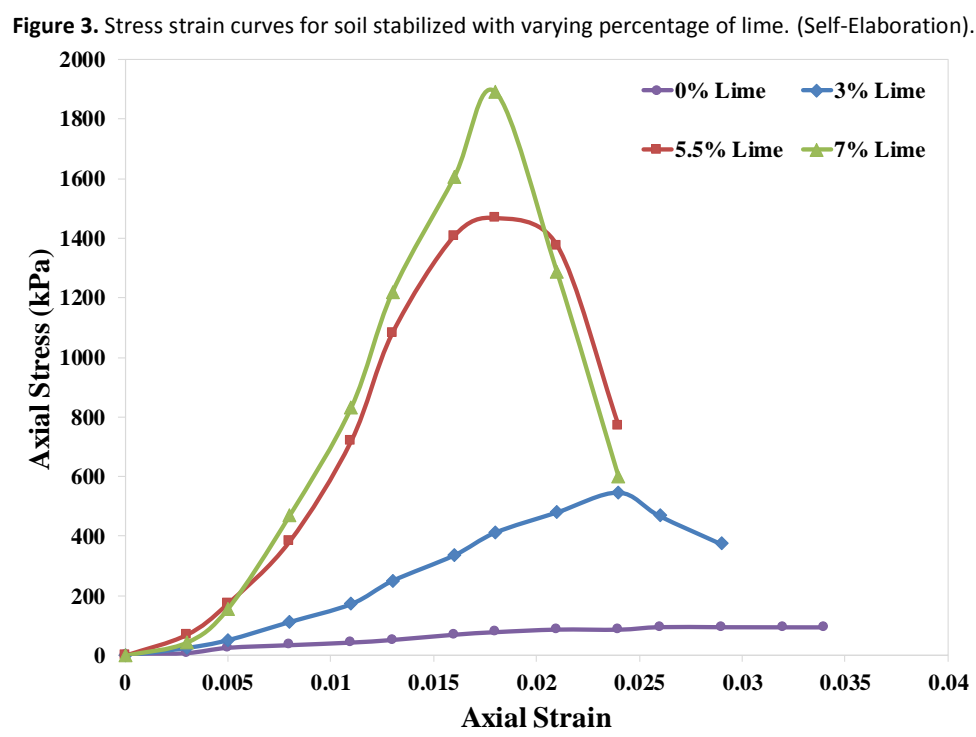

\section{Effect of lime content on plasticity}

Figure 4 reveals the effect of increasing quantities of lime adopted in this study on the virgin expansive soil. It can be seen that the addition of lime results in a steady reduction in the liquid limit of the virgin soil. The liquid limit reduced from $68 \%$ to around $49 \%$ on addition of $7 \mathrm{wt}$. \% lime. On the other hand, the plastic limit increased from $27 \%$ to close to $37 \%$ for $7 \mathrm{wt}$. \% addition of lime. The increase in plastic limit was steady till $5.5 \mathrm{wt}$. \% lime addition but further increase in lime did not result in a significant increase in the plastic limit as seen from the slope of the two sections of the curve. The combined effect of these two properties can be seen in plasticity index which reduced from $41 \%$ to around $12 \%$ when lime content increased from 0 to $7 \mathrm{wt}$. \%. The reduction in plasticity index was also significant till $5.5 \%$ and became marginal thereafter. The changes to Atterberg limits are due to ion exchange reactions and flocculation-aggregation of the clay particles due to addition of lime (Little, 1995). Mohammed \& Elsharief (2015) found that addition of hydrated lime resulted in a reduction in liquid limit and increase in plastic limit of expansive soils treated with hydrated lime. However, they found that reduction in plasticity was not significant beyond the lime fixation point which was also the case in the present study. Similar results wherein higher lime contents had little effect on plastic limit and plasticity index was also reported by others (Leite, Cardoso, Cardoso, Cavalcante, \& Freitas, 2016).

\section{Effect of lime content on swell-shrink}

Figure 5 shows the effect of lime on the free swell index and shrinkage limit of the virgin soil. It can be seen that the addition of lime resulted in the reduction in the free swell of the virgin soil with increasing lime content. The free swell reduced from close to $100 \%$ for virgin soil to just $50 \%$ for $3 \mathrm{wt}$. $\%$ addition of lime. With further increase in the lime content, the free swell reduced continuously to just around $8 \%$ for $7 \mathrm{wt}$. \% addition of lime. Leite et al. (2016) found that addition of just $3 \mathrm{wt}$. \% lime reduced the free swell of the soil from $20 \%$ to $1.85 \%$. Reduction due to further increase in lime contents of $6 \mathrm{wt}$. \% and $9 \mathrm{wt}$. \% were $1 \%$ and $0.5 \%$ respectively. Thus, it can be seen that significant reduction in swell is achieved by the first increment in lime content, a fact also reported by Thompson (1967). The shrinkage limit of 
the soil, on the other hand, increases with the increase in lime content of the soil. However, the increase in shrinkage limit is not as prominent as the reduction in the free swell due to addition of lime. The shrinkage limit increases from just $10 \%$ for virgin soil to around $17 \%$ for $3 \mathrm{wt}$. \% addition of lime. This continues to increase to $27 \%$ for $5.5 \mathrm{wt}$. \% lime modification. However, the increase in shrinkage limit reduces for further increase in the lime content. The shrinkage limit reaches a value of around 31\% for $7 \mathrm{wt}$. \% addition of lime to the soil. Thompson (1967) reported substantial increase in shrinkage limits of lime treated soils. Samantasinghar (2014) found that shrinkage arrests due to addition of lime to soil was because of flocculation of soil particles leading to reduction in specific surface area and double layer thickness.
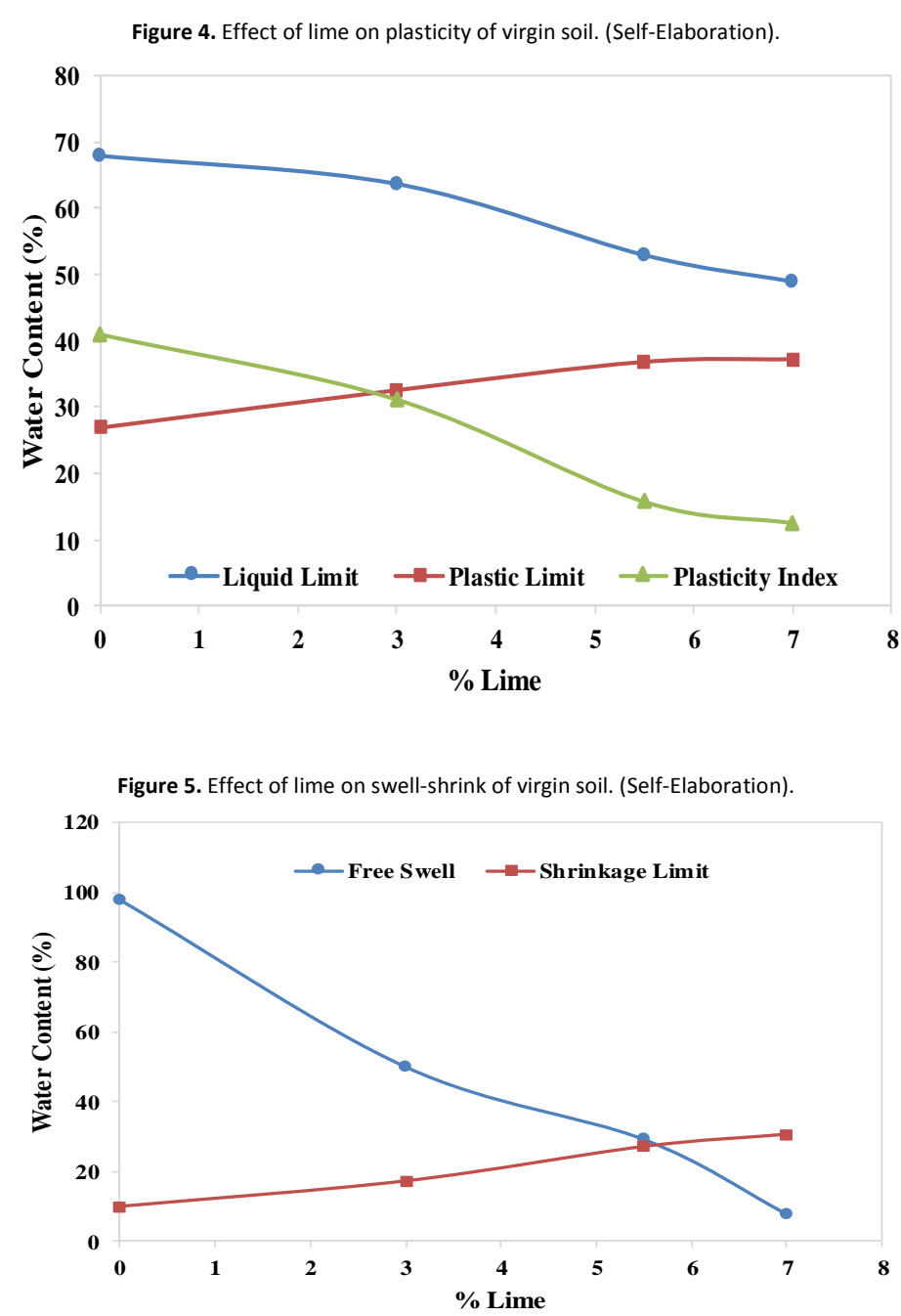

\section{Effect of CD on lime stabilization}

The effect of CD on the strength of lime stabilized soil was studied by performing UCS test to understand the effect of $\mathrm{CD}$ content and the curing period provided for the reactions to proceed.

\section{Effect of CD content}

The effect of $C D$ on lime stabilization strength was studied by adding CD in increasing proportion to lime soil mix for 3 wt. \%, 5.5 wt. \% and 7 wt. \% lime doses. Figure 6 shows the effect of addition of CD to 3 wt. \% lime stabilized soil. At 2 hours of curing, the addition of CD to lime stabilized soil has no significant effect on the strength as seen from the flat nature of the curve. There is a significant gap in the strength curve for 2 hours and 3-day curing, indicating a rapid development in strength at early period. At early curing, the addition of $C D$ also does not improve the strength. However, beyond 3 days of curing, the curves are spaced closer indicating a slowing down in the development of strength. The reason for the retardation of strength development may be due to the fact that $3 \mathrm{wt}$. \% lime is below the minimum lime required for modification of the soil under investigation. It is well documented in literature that lime above the ICL is required for development of strength of the stabilized soil. But the influence of the addition of CD can be seen with an increase in strength of the lime stabilized soil at $0.5 \mathrm{wt}$. \% dosage of the same. At $0.5 \mathrm{wt}$. \% CD, after 28 
days of curing, the strength of lime stabilized soil increased from $547.48 \mathrm{kPa}$ to $613.3 \mathrm{kPa}$, which is a gain of $12 \%$, indicating it to be the optimal dosage of $C D$.

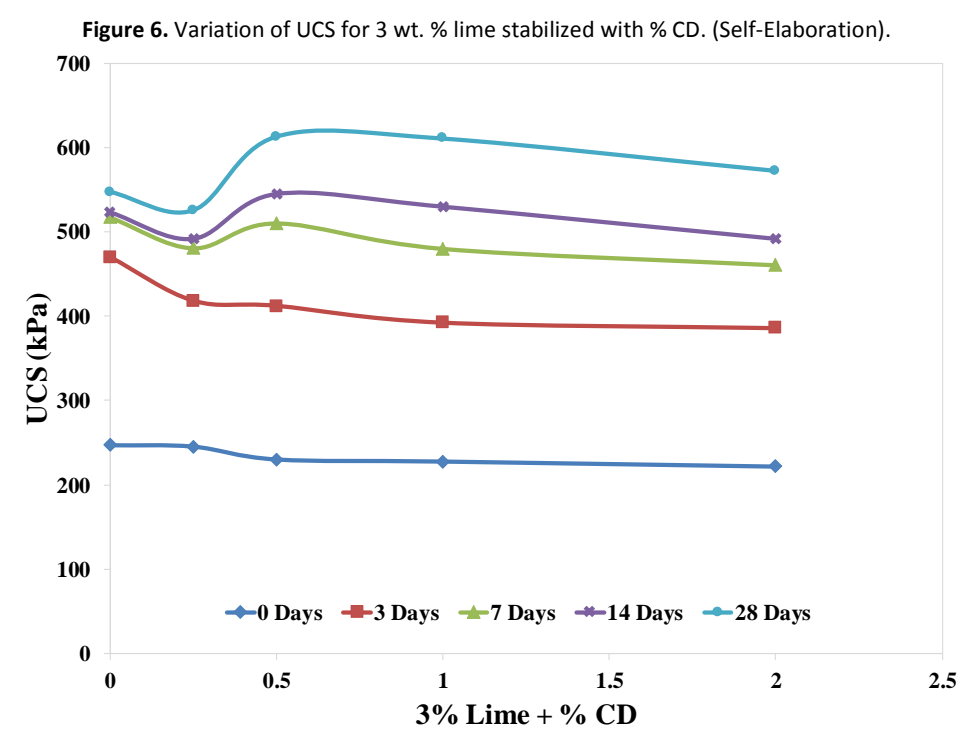

Figure 7 shows the UCS of ICL content stabilized soil. It can be seen that the addition of CD to lime stabilized soil at ICL also results in an increase in strength till $0.5 \mathrm{wt}$. \% addition beyond which there is a reduction in the strength of the stabilized soil. The figure sheds light on the fact that even at ICL, the addition of CD does not produce any significant beneficial effect at early curing of 2 hours and 3 days. Only after 7 days of curing, does the curve show a clear demarcation revealing the effect of addition of CD. CD amendment of lime stabilized soil results in augmented strength at a dosage of $0.5 \mathrm{wt}$ \% CD. The addition of $0.5 \mathrm{wt}$. \% CD to ICL content stabilized soil leads to a strength increase from $1398.77 \mathrm{kPa}$ to $1595.38 \mathrm{kPa}$, a gain of $196.61 \mathrm{kPa}$. This amounts to a gain of $14 \%$ in comparison with pure lime stabilized soil.

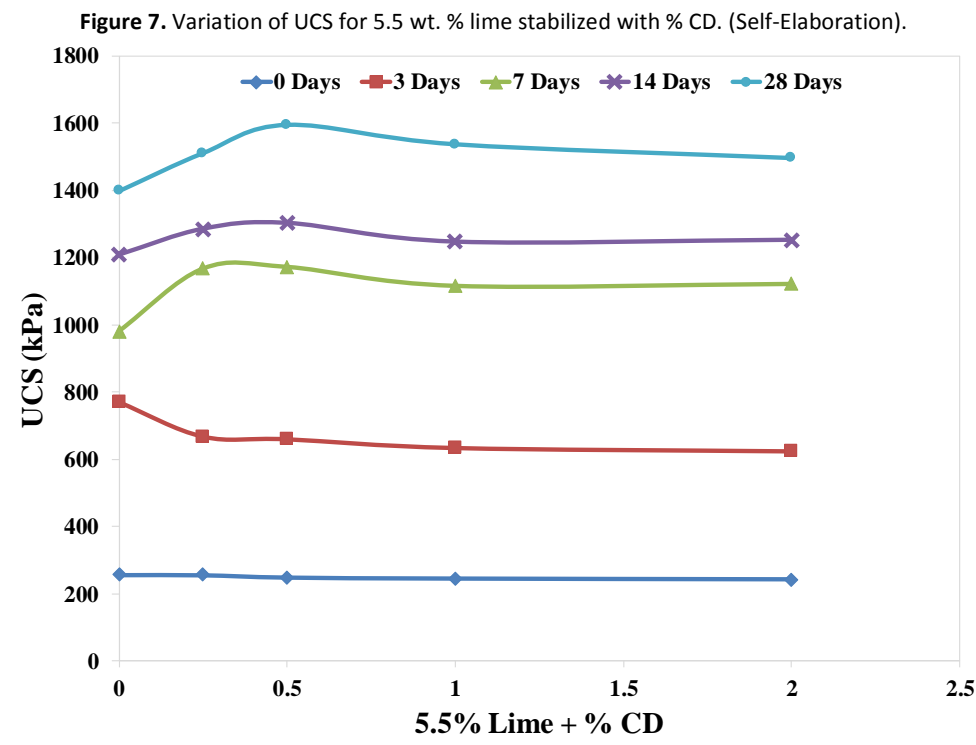

Figure 8 shows the effect of addition of CD to 7 wt. \% lime stabilized soil. At 2 hours of curing, there is no effect of CD on the strength of the stabilized soil. At 3 days of curing, there is a marginal increase in the strength at $0.5 \mathrm{wt}$. $\%$ addition of $\mathrm{CD}$. Beyond 3 days, there is a clear demarcation of the strength gain at $0.5 \mathrm{wt}$. \% addition of $\mathrm{CD}$, with a jump in strength in all curves. The strength of the $7 \mathrm{wt}$. \% lime stabilized soil, after 28 days of curing, increased from 1881.45 $\mathrm{kPa}$ to $2154.51 \mathrm{kPa}$, on $0.5 \mathrm{wt}$. \% addition of $\mathrm{CD}$ which is a gain of $14.5 \%$. In this case as well, the maximum gain in strength was achieved at a dosage of $0.5 \mathrm{wt}$. \% CD. Comparing all three cases of lime stabilization, all of them produced enhanced strength at $0.5 \mathrm{wt}$. \% dosage of CD. The maximum strength of the stabilized soil was obtained at OLC for 0.5 wt. \% CD addition. However, this was in contrast to the literature reported by Bakolas et al. (2008) wherein the lime consumption increased with increasing $\mathrm{CD}$ /lime ratios in lime mortars indicated by strength values. 


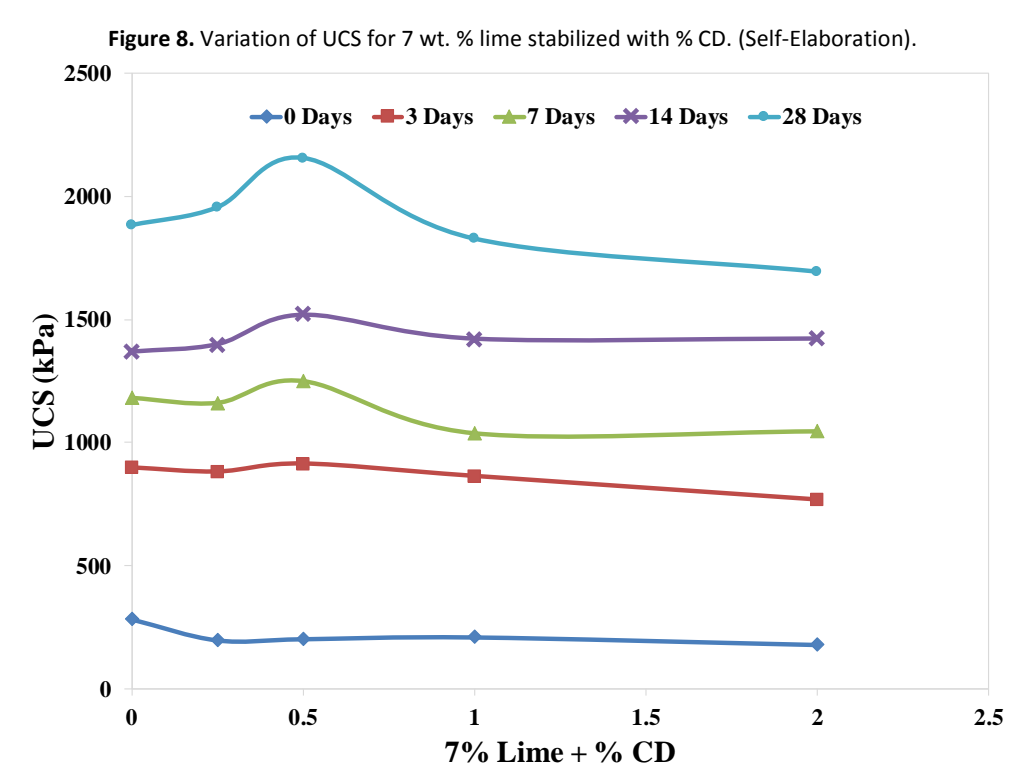

\section{Effect of curing}

It is a known fact that provision of curing period results in the improvement of strength of lime stabilized soil systems. In the present study, in order to study the effect of curing period on the strength development due to the addition of CD, strength development of pure lime stabilized soil was compared with lime stabilized soil admixed with CD. Figure 9 shows the effect of curing on the stabilized soil with and without the addition of CD. It can be seen that at $3 \mathrm{wt}$. \% lime stabilization, the addition of $C D$ has not produced a significant increase in the strength of the soil on providing curing. However, at $5.5 \mathrm{wt}$. \% and $7 \mathrm{wt}$. \% lime stabilization of soil, with increasing curing there is significant difference between the strength development of lime stabilized soil with and without CD. CD being an artificial pozzolan, provision of sufficient curing period and availability of sufficient lime has resulted in better strength of the stabilized soil.

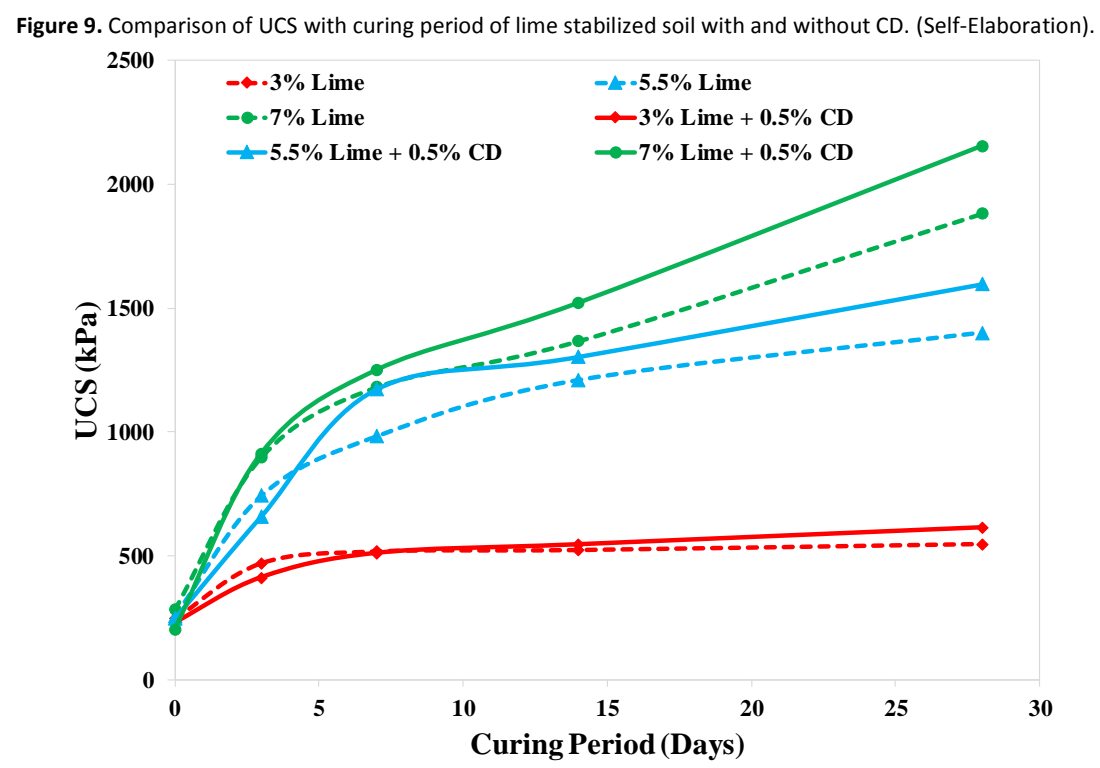

However, it may be noted that at early curing period, in all cases of lime stabilization, addition of CD has resulted in a slight dip in the development of early strength of the stabilized soil. However, this dip in the early strength is mitigated with increase in lime content. Whilst in less than ICL content, it takes 14 days for the CD amended specimen to gain strength over the pure lime stabilized soil, in the case of ICL it is just 7 days, whereas at OLC stabilization it takes just 3 days to gain strength over the pure lime stabilized soil. Moropoulou et al. (2005) reported that lime mortar with ceramic powder produced low compressive strengths at early curing but developed very high strengths at late curing period, even higher than natural lime mortars with which the present study is in agreement with. It can hence be concluded that $C D$ addition to lime stabilization results in enhanced strength but only when sufficient curing period is allowed for. Pacheco-Torgal \& Jalali (2010) also found that when ceramic powder was used as a replacement for cement, it resulted in a reduced early strength at 7 days of curing when compared to conventional cement concrete, but the delayed 
strength of the concrete was very close to the control value. However, in contrast, when CD was used as an additive to cement by James \& Pandian (2014a), CD resulted in enhanced early strength of the cement stabilized soil. In the present study, the early strength of the lime stabilized soil amended with CD was lower than the control specimen, however, the delayed strength at 28 days was higher for optimal dosage of CD. Hence, CD can be effectively suggested as an admixture to lime stabilization wherein the early strength of the stabilized soil is not significant for the application under consideration. Therefore, CD can be recommended as a deferred strength enhancer.

\section{Effect of CD on plasticity and swell-shrink}

Figure 10 shows the plasticity of all three lime stabilized soils amended with the optimal dosage of CD namely 0.5 wt. $\%$. It is noticeable that the effect of $C D$ in reducing plasticity is higher at low lime content of 3 wt. \%. At higher lime content of $5.5 \mathrm{wt}$. \% and $7 \mathrm{wt}$. \%, the effect of addition of CD in reducing plasticity reduces comparatively. Thus, it can be inferred that at insufficient lime content, $C D$ augments the performance of lime in reducing plasticity whereas when sufficient lime is available, lime dominates the plasticity modification thereby reducing CD effect to minor variations.

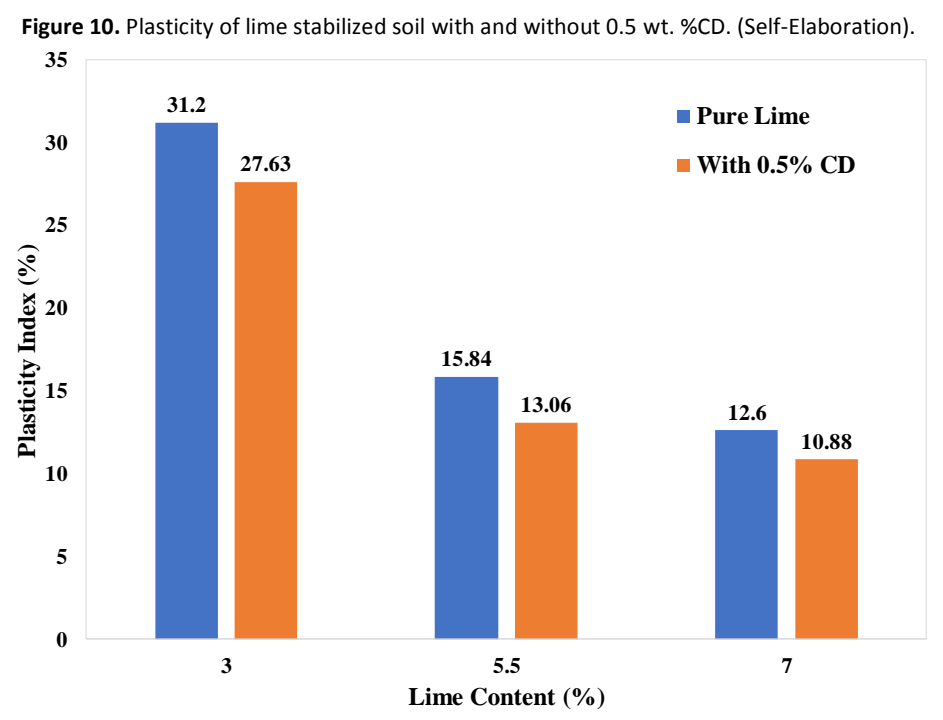

Figure 11 shows the effect of addition of optimal dosage of CD on the free swell index of lime stabilized soil. It can be seen that the addition of $C D$ to the lime stabilized soil results in a further reduction in the free swell of the stabilized soil. The reduction in free swell is higher when the lime content is lower. At higher lime content, the reduction in free swell is marginal as already the addition of lime has resulted in significant reduction in the free swell of the soil. Sabat (2012) and Chen \& Idusuyi (2015) found that addition of CD to expansive soil resulted in a reduction in swell pressure of the soil attributed to replacement of swelling clay particles with non-swelling CD particles. Sabat \& Bose (2014) reported that addition of up to $35 \% \mathrm{CD}$ to fly ash-lime stabilized soil reduced the swell pressure of the soil to zero. They cited replacement of stabilized clay particles with CD particles and formation of strong inter particle bonds between soil, fly ash-lime and CD as reasons for reduction in swell of the stabilized soil. In the present work, the reduction in free swell may be due to a combination of chemical reaction products of lime soil-CD and presence of non-swelling coarser CD particles.

Figure 12 shows the effect of addition of $0.5 \mathrm{wt}$. \% CD on the shrinkage limit of lime stabilized expansive soil. The addition of $C D$ results in a further increase in shrinkage limit of the soil indicating further improvement in swell-shrink nature of the soil. The maximum increase in shrinkage limit is obtained at ICL stabilization. Increase in shrinkage limit results in a reduction in the range over which volume change can occur (James, Lakshmi, Pandian, \& Aravindan, 2014), thereby improving its volume change behaviour. Sabat \& Nanda (2011) stated that pozzolanic products formed due to reaction between lime present in marble dust and silica and alumina present in soil and RHA resulted in strong inter-particle bonds which does not allow water to escape from soil and hence, reduces shrinkage. A similar mechanism in the present case may be the reason for reduced shrinkage. 

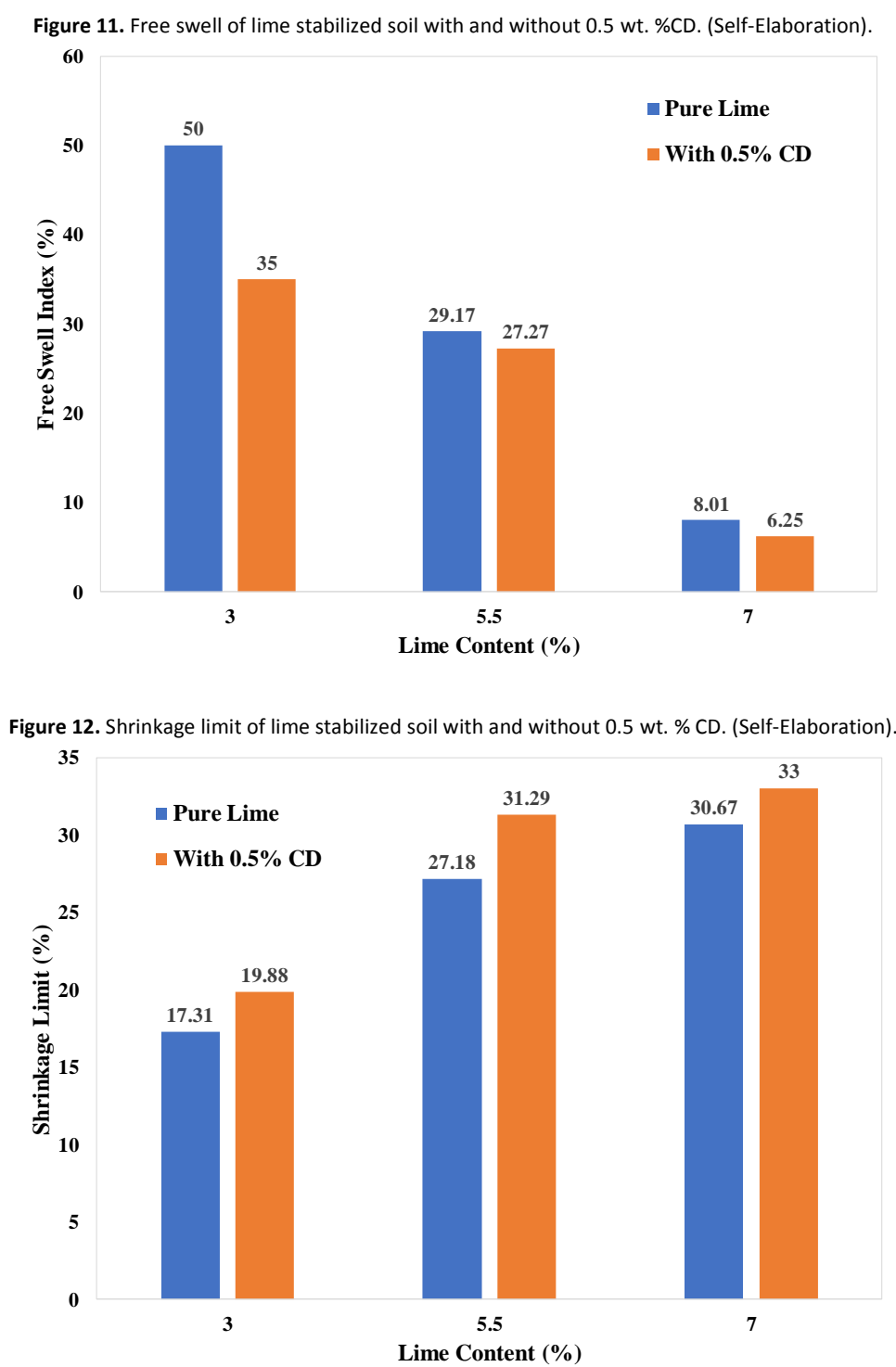

\section{Mineralogy of CD admixed lime soil stabilization}

Admixing lime-soil system with CD results in the augmentation of formation of calcium silicate hydrate (CSH) and calcium aluminate hydrate $(\mathrm{CAH})$ minerals. Figure 13 reveals the minerals formed due to pozzolanic reactions between soil, lime and $C D$. It can be seen that addition of CD to lime stabilized soil augments the availability of silica and alumina in the reactions leading to the formation of CSH and CAH minerals. The CSH minerals formed include Rosenhahnite, Calcium chondrolite, $\alpha-\mathrm{C}_{2} \mathrm{SH}$, Killalaite, Suolunite, Poldervaartite and Wollastonite. The CAH minerals include Tetracalcium dialuminium pentahydrate and Hydrogarnet. The high $\mathrm{pH}$ environment during lime stabilization results in the destruction of crystal structure of silica and alumina due to dissolution. This leads to reduction in intensity of peaks of minerals rather than their complete disappearance due to stabilization reactions. New peaks intensities also grow corresponding new minerals that form due to the stabilization reactions.

In the present case, the intensity of quartz at 2-theta value of $26.68^{\circ}$ reduced from 16904 counts in virgin soil to 2043 counts when it was stabilized with $7 \mathrm{wt}$. \% lime. However, on addition of $0.5 \mathrm{wt} . \% \mathrm{CD}$ to this mix, the intensity further reduced to 727 counts. The peak corresponding to montmorillonite at 2-theta value of $19.78^{\circ}$ reduced from 2082 counts in virgin soil to 941 counts in $7 \mathrm{wt}$. \% lime stabilized soil which further reduced to 736 counts upon addition of $0.5 \mathrm{wt}$. $\% \mathrm{CD}$. This indicates that the addition of $\mathrm{CD}$ to the stabilization process enables better progress of the pozzolanic reactions resulting in the destruction of crystal structure of minerals and hence, reflecting as reduced intensity of peaks in diffraction tests. Literature suggests that the major composition of CD is silica and alumina (Halicka et al., 2013; Pacheco-Torgal \& Jalali, 2010; Reig, Tashima, Soriano, Borrachero, Monzo, et al., 2013; Tavakoli et al., 2013). CD being a known artificial pozzolan, these components reacts with calcium from lime to result in the formation of CSH and CAH. However, Pacheco-Torgal \& Jalali (2010) also mention that white paste CD has a small but significant proportion of calcium oxide as well. In soils with lesser quantities of natural silica and alumina, addition of CD will result in better strength due to the augmentation of the available silica and alumina for pozzolanic reactions to proceed. Bakolas et al. 
(2008) found the formation of calcium aluminium oxide carbonate hydroxide hydrate $\left(\mathrm{C}_{4} \mathrm{ACcH}_{11}\right)$ as a result of reaction between ceramic paste and hydrated lime through X-ray diffraction studies. Bakolas, Aggelakopoulou, Moropoulou, \& Anagnostopoulou (2006) also reported earlier that Monocarboaluminate $\left(\mathrm{C}_{4} A \mathrm{CH}_{11}\right)$ is formed as a result of reaction between calcium hydroxide, alumina and silica.

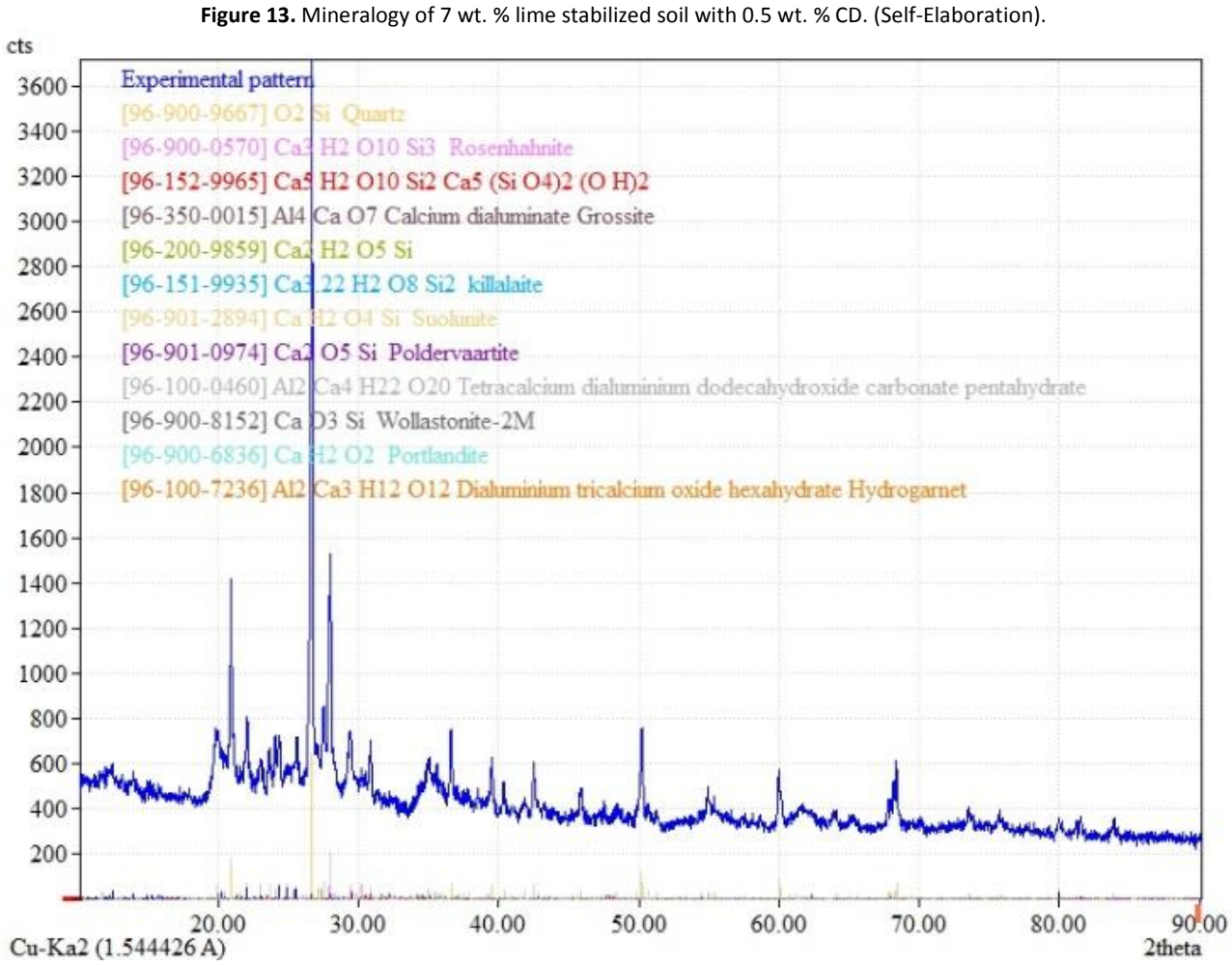

\section{Microstructural study}

Figure 14 shows the composite image of untreated expansive soil at $2000 x$ and soil stabilized with 7 wt. $\%$ lime and 0.5 wt. \% CD at 5000x magnification. The addition of lime and CD to soil has resulted in a change in the appearance of the soil due to the chemical reactions taking place in the soil. The virgin soil can be seen aggregated into lumps due to cohesive nature of the clayey soil. However, on closer observation it can be seen that the lumps consist of platy clay particles that are stuck to each other. Due to stabilization of the soil, there is significant change in the microstructure of the soil. The platy aggregated clay particles can no longer be seen in the stabilized soil matrix. This is due to the destruction of their crystal structure due to the dissolution of soil silica and alumina due to the high pH environment developed during addition of lime to soil. Consequently, the stabilized soil exhibits, a dense and compact microstructure. There appears to be what seems like foil like leafy structures dispersed in random direction indicating the destruction of platy clay particles and formation and deposition of new reaction products. Bhuvaneshwari et al. (2013) also reported development of such a microstructure in lime stabilized soil. The microstructure also appears to have more cementitious connectors resulting in well-developed floccules. Sante, Fratalocchi, Mazzieri, \& Pasqualini (2014) also reported the formation such floccules in lime stabilized soil. The stabilized soil matrix also exhibits very little voids which may be due to the deposition of cementitious products resulting in a denser microstructure.

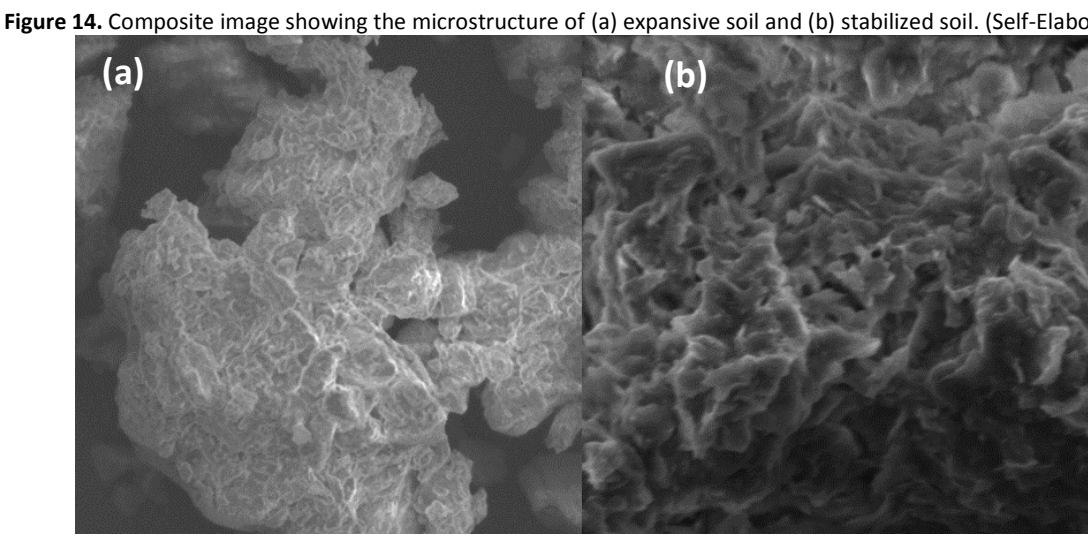


The investigation involved the amendment of lime stabilized soil with various dosages of CD followed by strength, plasticity, swell-shrink, mineralogy and microstructural evaluation. Based on the results of the various tests carried out on virgin and stabilized soil specimens, the following points can be concluded:

- Stabilization of the expansive soil with lime resulted in an increase in strength and stiffness of the soil and reduction in plasticity and swell-shrink nature with increase in lime content. Amendment of the three lime contents with $C D$ in the process of stabilization resulted in a further increase in strength of the stabilized soil. CD was able to enhance the strength of the lime stabilized soil, irrespective of the lime content adopted for stabilization. However, it was found that $0.5 \mathrm{wt}$. \% CD dosage was the optimal dosage for all three lime contents. The optimal dosage of CD to lime stabilization resulted in $12-14 \%$ gain in strength of the stabilized soil after 28 days of curing.

- Addition of CD to lime stabilization resulted in an increase in strength of the lime stabilized soil after 28 days of curing, irrespective of lime content but the development of very early strength, at 3 days of curing, was hampered by the addition of CD. This delay in strength development, however, was partially overcome with increase in lime content of the stabilization process. Thus, higher lime content with $C D$ can overcome the delay in strength development at early curing due to the presence of $C D$.

- $C D$ amendment of lime stabilization resulted in a further reduction in plasticity and swell-shrink nature of the stabilized soil. However, the effect of CD was more pronounced at lower lime content when compared to higher lime content.

- Mineralogical investigation of the stabilized soil samples revealed the reduction in peaks of quartz and montmorillonite due to stabilization of soil with lime and CD with an increased suppression seen on addition of CD. This can be indicative of effective progress of pozzolanic reaction and formation of reaction products resulting in enhanced strength gain noticed due to addition of $C D$ to lime stabilized soil. The reactions products formed were minerals of $\mathrm{CSH}$ and $\mathrm{CAH}$ group, which resulted in an enhanced strength of the stabilized soil.

- The microstructural study of virgin and stabilized soil indicated destruction of the platy clay particles and formation of cementitious depositions resulting in better aggregation of the soil particles and formation of a compact and dense microstructure.

Thus, it can be concluded that CD can be used as an effective admixture in the enhancement of strength of lime stabilization of expansive soils wherein provision of sufficient curing time is possible for development of strength. In cases, wherein early strength gains prominence, higher lime content can be adopted to overcome the delay in development of strength due to $C D$ at early curing periods.

\section{Acknowledgements}

The authors are indebted to the management of Tagore Engineering College, Chennai, India, for providing the research facilities needed to carry out this work. The authors would like to record their deep sense of gratitude towards SAIF, IITBombay, Mumbai, India and Anna University, Chennai, India for providing XRF and SEM \& XRD facilities respectively. The authors would like to thank Mr. M. Sasi Kumar, Lab Instructor, Soil Engineering Laboratory and students of B.E., Civil Engineering, Tagore Engineering College, Chennai, India, for helping out in the testing work. The authors also thank the reviewers for providing constructive feedback which was greatly helpful in enhancing the quality of this article.

References

Al-Mukhtar, M., Khattab, S., \& Alcover, J. (2012). Microstructure and geotechnical properties of lime-treated expansive clayey soil. Engineering Geology, 139, 17-27. http://doi.org/10.1016/j.enggeo.2012.04.004

Al-Mukhtar, M., Lasledj, A., \& Alcover, J. (2010a). Behaviour and mineralogy changes in lime-treated expansive soil at $50^{\circ}$ C. Applied Clay Science, 50(2), 199-203. http://doi.org/10.1016/j.clay.2010.07.022

Al-Mukhtar, M., Lasledj, A., \& Alcover, J.-F. (2010b). Behaviour and mineralogy changes in lime-treated expansive soil at $20^{\circ} \mathrm{C}$. Applied Clay Science, 50(2), 191-198. http://doi.org/10.1016/j.clay.2010.07.023

Al-Rawas, A. A., Taha, R., Nelson, J. D., Al- Shab, T. B., \& Al-Siyabi, H. (2002). A Comparative Evaluation of Various Additives Used in the Stabilization of Expansive Soils. ASTM Geotechnical Testing Journal, 25(2), 199-209. http://doi.org/10.1520/GTJ11363J

Aldaood, A., Bouasker, M., \& Al-Mukhtar, M. (2014a). Free swell potential of lime-treated gypseous soil. Applied Clay Science, 102, 93-103.

Aldaood, A., Bouasker, M., \& Al-Mukhtar, M. (2014b). Geotechnical properties of lime-treated gypseous soils. Applied Clay Science, 88, 39-48. http://doi.org/10.1016/j.clay.2013.12.015

Aldaood, A., Bouasker, M., \& Al-Mukhtar, M. (2014c). Impact of freeze - thaw cycles on mechanical behaviour of lime stabilized gypseous soils. Cold Regions Science and Technology, 99, 38-45. 
Aldaood, A., Bouasker, M., \& Al-Mukhtar, M. (2014d). Impact of wetting-drying cycles on the microstructure and mechanical properties of limestabilized gypseous soils. Engineering Geology, 174, 11-21. http://doi.org/10.1016/j.enggeo.2014.03.002

Alzubaidi, R., \& Lafta, S. H. (2013). Effect of Strain Rate on the Strength Characteristics of Soil-Lime Mixture. Geotechnical and Geological Engineering, 31(4), 1317-1327. http://doi.org/10.1007/s10706-013-9653-3

Ameta, N. K., Wayal, A. S., \& Hiranandani, P. (2013). Stabilization of Dune Sand with Ceramic Tile Waste as Admixture. American Journal of Engineering Research, 2(9), 133-139.

Anwar, A., Ahmad, S., Mohammed, S., Husain, A., \& Ahmad, S. A. (2015). Replacement Of Cement By Marble Dust And Ceramic Waste In Concrete For Sustainable Development. International Journal of Innovative Science, Engineering \& Technology, 2(6), 496-503.

ASTM. D6276 Standard Test Method for Using pH to Estimate the Soil-Lime Proportion Requirement (2006). United States.

Bakolas, A., Aggelakopoulou, E., \& Moropoulou, A. (2008). Evaluation of pozzolanic activity and physico-mechanical characteristics in ceramic powderlime pastes. Journal of Thermal Analysis and Calorimetry, 92(1), 345-351. http://doi.org/10.1007/s10973-007-8858-1

Bakolas, A., Aggelakopoulou, E., Moropoulou, A., \& Anagnostopoulou, S. (2006). Evaluation of Pozzolanic Activity and Physico- Mechanical Characteristics in Metakaolin-Lime Pastes. Journal of Thermal Analysis and Calorimetry, 84(1), 157-163.

Bell, F. G. (1996). Lime stabilization of clay minerals and soils. Engineering Geology, 42(4), 223-237. http://doi.org/10.1016/0013-7952(96)00028-2

Bhuvaneshwari, S., Robinson, R. G., \& Gandhi, S. R. (2013). Behaviour of Lime Treated Cured Expansive Soil Composites. Indian Geotechnical Journal, 44(3), 278-293. http://doi.org/10.1007/s40098-013-0081-3

Bhuvaneswari, S., Thyagaraj, T., Robinson, R. G., \& Gandhi, S. R. (2010). Alternative Technique to Induce Faster Lime Stabilization Reaction in Deeper Expansive Strata. In Proceedings of Indian Geotechnical Conference - 2010, GEOtrendz, December 16-18, Mumbai, India, p (pp. 609-612). Mumbai, India.

BIS. IS 1498 Classification and Identification of Soils for General Engineering Purposes (1970). India.

BIS. IS 2720 Methods of Test for Soils:Part 6 Determination of Shrinkage Factors (1972). India.

BIS. IS 2720 Methods of Test for Soils:Part 40 Determination of Free Swell Index of Soils (1977). India.

BIS. IS 2720 Methods of Test for Soils:Part 7 Determination of Water Content-Dry Density Relation Using Light Compaction (1980). India.

BIS. IS 2720 Methods of Test for Soils Part 3:Determination of Specific Gravity/Section 1 Fine Grained Soils (1980). India.

BIS. IS 2720 Methods of Test For Soils:Part 1 - Preparation of Dry Soil Sample for Various Tests (1983). India.

BIS. IS 2720 Methods of Test for Soils:Part 4 Grain Size Analysis (1985). India.

BIS. IS 2720 Methods of Test for Soils:Part 5 Determination of Liquid and Plastic Limit (1985). India.

BIS. IS 2720 Methods of Test for Soils:Part 26 Determination of pH (1987). India.

BIS. IS 2720 Methods of Test for Soils:Part 10 - Determination of Unconfined Compressive Strength (1991). India.

Bozbey, I., \& Garaisayev, S. (2010). Effects of soil pulverization quality on lime stabilization of an expansive clay. Environmental Earth Sciences, 60(6), 1137-1151. http://doi.org/10.1007/s12665-009-0256-5

Calik, U., \& Sadoglu, E. (2013). Classification, shear strength, and durability of expansive clayey soil stabilized with lime and perlite. Natural Hazards, 71(3), 1289-1303. http://doi.org/10.1007/s11069-013-0950-1

Celik, E., \& Nalbantoglu, Z. (2013). Effects of ground granulated blastfurnace slag (GGBS) on the swelling properties of lime-stabilized sulfate-bearing soils. Engineering Geology, 163, 20-25. http://doi.org/10.1016/j.enggeo.2013.05.016

Centre for Science and Environment. (2014). Construction and Demolition Waste. New Delhi, India.

Chen, J. A., \& Idusuyi, F. O. (2015). Effect of Waste Ceramic Dust (WCD) on Index and Engineering Properties of Shrink-Swell Soils. International Journal of Engineering and Modern Technology, 1(7), 1-11.

Dahale, P. P., Nagarnaik, P. B., \& Gajbhiye, A. R. (2012). Utilization of Solid Waste for Soil Stabilization : A Review. Electronic Journal of Geotechnical Engineering, 17(Bund Q), 2443-2461.

Eades, J. L., \& Grim, R. E. (1966). A Quick Test to Determine Lime Requirements for Lime Stabilization. Highway Research Record, $139,61-72$.

Eisazadeh, A., Kassim, K. A., \& Nur, H. (2011a). Characterization of phosphoric acid- and lime-stabilized tropical lateritic clay. Environmental Earth Sciences, 63, 1057-1066. http://doi.org/10.1007/s12665-010-0781-2

Eisazadeh, A., Kassim, K. A., \& Nur, H. (2011b). Stabilization of tropical kaolin soil with phosphoric acid and lime. Natural Hazards, 61(3), 931-942. http://doi.org/10.1007/s11069-011-9941-2

Far, S. Y. Z., Kassim, K. A., Eisazadeh, A., \& Khari, M. (2013). An Evaluation of the Tropical Soils Subjected Physicochemical Stabilization for Remote Rural Roads. Procedia Engineering, 54, 817-826. http://doi.org/10.1016/j.proeng.2013.03.075

Fityus, S., \& Buzzi, O. (2009). The place of expansive clays in the framework of unsaturated soil mechanics. Applied Clay Science, 43(2), $150-155$. http://doi.org/10.1016/j.clay.2008.08.005

Garzón, E., Cano, M., O`Kelly, B. C., \& Sánchez-Soto, P. J. (2016). Effect of lime on stabilization of phyllite clays. Applied Clay Science, 123, $329-334$. http://doi.org/10.1016/j.clay.2016.01.042 
Geeta Rani, T., Shivanarayana, Prasad, D. S. V, \& Prasada Raju, G. V. R. (2014). Strength Behaviour of Expansive Soil Treated with Tile Waste. International Journal of Engineering Research and Development, 10(12), 52-57. Retrieved from http://ijerd.com/paper/vol10issue12/Version_3/G10125257.pdf

George, S. Z., Ponniah, D. A., \& Little, J. A. (1992). Effect of temperature on lime-soil stabilization. Construction and Building Materials, 6(4), $247-252$. http://doi.org/10.1016/0950-0618(92)90050-9

Halicka, A., Ogrodnik, P., \& Zegardlo, B. (2013). Using ceramic sanitary ware waste as concrete aggregate. Construction and Building Materials, 48, 295-305. http://doi.org/dx.doi.org/10.1016/j.conbuildmat.2013.06.063

James, J., Lakshmi, S. V., Pandian, P. K., \& Aravindan, S. (2014). Effect of Lime on the Index Properties of Rice Husk Ash Stabilized Soil. International Journal of Applied Engineering Research, 9(18), 4263-4272.

James, J., \& Pandian, P. K. (2013). Performance Study on Soil Stabilisation using Natural Materials. International Journal of Earth Sciences and Engineering, 6(1), 194-203.

James, J., \& Pandian, P. K. (2014a). A Study on the Early UCC Strength of Stabilized Soil Admixed with Industrial Waste Materials. International Journal of Earth Sciences and Engineering, 7(3), 1055-1063. Retrieved from www.cafetinnova.org

James, J., \& Pandian, P. K. (2014b). Effect of Phosphogypsum on the Strength of Lime Stabilized Expansive Soil. Gradevinar, 66(12), 1109-1116. http://doi.org/10.14256/JCE.1097.2014

James, J., \& Pandian, P. K. (2015). Soil Stabilization as an Avenue for Reuse of Solid Wastes : A Review. Acta Technica Napocensis: Civil Engineering and Architechture, 58(1), 50-76.

James, J., \& Pandian, P. K. (2016a). Industrial Wastes as Auxiliary Additives to Cement / Lime Stabilization of Soils. Advances in Civil Engineering, 2016(Article ID 1267391), 1-17. http://doi.org/doi.org/10.1155/2016/1267391

James, J., \& Pandian, P. K. (2016b). Plasticity, Swell-Shrink and Microstructure of Phosphogypsum Admixed Lime Stabilized Expansive Soil. Advances in Civil Engineering, 2016(Article ID 9798456), 1-10.

Kamala, R., \& Rao, B. K. (2012). Reuse of Solid Waste from Building Demolition for the Replacement of Natural Aggregates. International Journal of Engineering and Advanced Technology, 2(1), 74-76.

Kavak, A., Bilgen, G., \& Faruk Capar, O. (2011). Using Ground Granulated Blast Furnace Slag with Seawater as Soil Additives in Lime-Clay Stabilization. Journal of ASTM International, 8(7), 1-12.

Kinuthia, J. M., Wild, S., \& Jones, G. I. (1999). Effects of monovalent and divalent metal sulphates on consistency and compaction of lime-stabilised kaolinite. Applied Clay Science, 14(1), 27-45. http://doi.org/10.1016/S0169-1317(98)00046-5

Kumar, A., Sharma, R. K., \& Singh, B. (2014). Compaction and Sub-grade Characteristics of Clayey Soil Mixed with Foundry Sand and Fly Ash and Tile Waste. IOSR Journal of Mechanical and Civil Engineering, (spl), 1-5.

Leite, R., Cardoso, R., Cardoso, C., Cavalcante, E., \& Freitas, O. De. (2016). Lime stabilization of expansive soil from Sergipe - Brazil. E3S Web of Conferences, 9, 1-6.

Little, D. N. (1995). Handbook for Stabilization of Pavement Subgrades and Base Courses with Lime. Austin, Texas.

Matias, G., Faria, P., \& Torres, I. (2014a). Lime mortars with ceramic wastes: Characterization of components and their influence on the mechanical behaviour. Construction and Building Materials, 73, 523-534. http://doi.org/10.1016/j.conbuildmat.2014.09.108

Matias, G., Faria, P., \& Torres, I. (2014b). Lime mortars with heat treated clays and ceramic waste: A review. Construction and Building Materials, 73, 125-136. http://doi.org/10.1016/j.conbuildmat.2014.09.028

Mavroulidou, M., Zhang, X., Gunn, M. J., \& Cabarkapa, Z. (2013). Water Retention and Compressibility of a Lime-Treated, High Plasticity Clay. Geotechnical and Geological Engineering, 31(4), 1171-1185. http://doi.org/10.1007/s10706-013-9642-6

Mishra, E. N. K. (2012). Strength Characteristics of Clayey Sub-Grade Soil Stabilized with Fly Ash and Lime for Road Works. Indian Geotechnical Journal, 42(3), 206-211. http://doi.org/10.1007/s40098-012-0015-5

Mohammed, A. A., \& Elsharief, A. M. (2015). Effects of Lime On The Engineering Properties Of Highly Expansive Soils From Sudan. International Journal of Science, Engineering and Technology Research (IJSETR), 4(10), 3595-3600.

Moropoulou, A., Bakolas, A., Moundoulas, P., Aggelakopoulou, E., \& Anagnostopoulou, S. (2005). Strength development and lime reaction in mortars for repairing historic masonries. Cement and Concrete Composites, 27(2), 289-294. http://doi.org/10.1016/j.cemconcomp.2004.02.017

Muhmed, A., \& Wanatowski, D. (2013). Effect of Lime Stabilisation on the Strength and Microstructure of Clay. IOSR Journal of Mechanical and Civil Engineering, 6(3), 87-94.

Nalbantoğlu, Z. (2004). Effectiveness of Class C fly ash as an expansive soil stabilizer. Construction and Building Materials, $18(6)$, 377-381. http://doi.org/10.1016/j.conbuildmat.2004.03.011

Nasrizar, A. A., Ilamparuthi, K., \& Muttharam, M. (2012). Quantitative Models for Strength of Lime Treated Expansive Soil. In GeoCongress 2012, March 25-29 (pp. 978-987). Oakland, California, US: American Society of Civil Engineers. http://doi.org/10.1061/9780784412121.101

Nasrizar, A. A., Muttharam, M., \& Illamparuthi, K. (2010a). Effect of placement water content on the strength of temperature cured lime treated expansive soil. In Proceedings of GeoShanghai 2010, June 3-5 (pp. 174-180). Shanghai, China.

Nasrizar, A. A., Muttharam, M., \& Illamparuthi, K. (2010b). Role of Lime Content on Soil-Lime Reaction under Thermal Curing. In Proceedings of Indian Geotechnical Conference - 2010, GEOtrendz, December 16-18 (pp. 595-598). Mumbai. 
Pacheco-Torgal, F., \& Jalali, S. (2010). Compressive strength and durability properties of ceramic wastes based concrete. Materials and Structures, 44(1), 155-167. http://doi.org/10.1617/s11527-010-9616-6

Prasad, A. S. S. V., Prasad, D. S. V, \& Babu, R. D. (2015). Efficiency of Calcium Chloride and Vitrified Tiles Sludge on the Strength Characteristics of Expansive Soil. International Journal of Advanced Research in Education and Technology, 2(3), 202-205.

Rajasekaran, G. (2005). Sulphate attack and ettringite formation in the lime and cement stabilized marine clays. Ocean Engineering, 32(8), $1133-1159$. http://doi.org/10.1016/j.oceaneng.2004.08.012

Rajasekaran, G., Murali, K., \& Srinivasaraghavan, R. (1997). Fabric and Mineralogical Studies on Lime Treated Marine Clays. Ocean Engineering, 24(3), 227-234.

Rajasekaran, G., \& Rao, S. N. (1997). The microstructure of lime-stabilized marine clay. Ocean Engineering, 24(9), 867-878.

Rajasekaran, G., \& Rao, S. N. (2002a). Compressibility behaviour of lime-treated marine clay. Ocean Engineering, $29(5)$, 545-559. http://doi.org/10.1016/S0029-8018(01)00010-5

Rajasekaran, G., \& Rao, S. N. (2002b). Permeability characteristics of lime treated marine clay. Ocean Engineering, 29(2), 113-127. http://doi.org/10.1016/S0029-8018(01)00017-8

Raval, A. D., Patel, D. I. N., \& Pitroda, P. J. (2013). Ceramic Waste : Effective Replacement Of Cement For Establishing Sustainable Concrete. International Journal of Engineering Trends and Technology (IJETT), 4(6), 2324-2329.

Reig, L., Tashima, M. M., Soriano, L., Borrachero, M. V., Monzó, J., \& Payá, J. (2013). Alkaline Activation of Ceramic Waste Materials. Waste and Biomass Valorization, 4(4), 729-736. http://doi.org/10.1007/s12649-013-9197-z

Reig, L., Tashima, M. M., Soriano, L., Borrachero, M. V, Monzo, J., \& Paya, J. (2013). Alkaline Activation of Ceramic Waste Materials. Waste and Biomass Valorization, 4(4), 729-736. http://doi.org/10.1007/s12649-013-9197-z

Sabat, A. K. (2012). Stabilization of Expansive Soil Using Waste Ceramic Dust. Electronic Journal of Geotechnical Engineering, 17(Bund. Z), 3915-3926. Retrieved from http://www.ejge.com/2012/Ppr12.369alr.pdf

Sabat, A. K., \& Bose, B. (2014). Strength, Swelling and Durability Characteristics of Fly-Lime Stabilized Expansive Soil-Ceramic Dust Mixes. International Journal of Earth Sciences and Engineering, 7(3), 1210-1215.

Sabat, A. K., \& Nanda, R. P. (2011). Effect of marble dust on strength and durability of Rice husk ash stabilised expansive soil. International Journal of Civil and Structural Engineering, 1(4), 939-948. http://doi.org/10.6088/ijcser.00202010080

Sabat, A., \& Pati, S. (2014). A Review of Literature on Stabilization of Expansive Soil Using Solid Wastes. Electronic Journal of Geotechnical Engineering, 19(Bund U), 6251-6267.

Sağın, E. U., Böke, H., Aras, N., \& Yalçın, Ş. (2012). Determination of CaCO3 and SiO2 content in the binders of historic lime mortars. Materials and Structures, 45(6), 841-849. http://doi.org/10.1617/s11527-011-9802-1

Samantasinghar, S. (2014). Geo-engineering Properties of Lime Treated Plastic Soils. M.Tech. Thesis. National Institute of Technology Rourkela.

Sante, M. Di, Fratalocchi, E., Mazzieri, F., \& Pasqualini, E. (2014). Time of reactions in a lime treated clayey soil and influence of curing conditions on its microstructure and behaviour. Applied Clay Science, 99, 100-109. http://doi.org/10.1016/j.clay.2014.06.018

Seco, A., Ramírez, F., Miqueleiz, L., \& García, B. (2011). Stabilization of expansive soils for use in construction. Applied Clay Science, 51(3), 348-352. http://doi.org/10.1016/j.clay.2010.12.027

Sekar, T., Ganesan, N., \& Nampoothiri, N. (2011). Studies on Strength Characteristics on Utilization of Waste Materials as Coarse Aggregate in Concrete. International Journal of Engineering Science and Technology, 3(7), 5436-5440.

Sharma, R. S., Phanikumar, B. R., \& Rao, V. B. (2008). Engineering Behavior of a Remolded Expansive Clay Blended with Lime , Calcium Chloride , and Rice-Husk Ash. Journal of Materials in Civil Engineering, 20(8), 509-515. http://doi.org/10.1061/(ASCE)0899-1561(2008)20:8(509)

Silva, J., De Brito, J., \& Veiga, R. (2008). Fine ceramics replacing cement in mortars Partial replacement of cement with fine ceramics in rendering mortars. Materials and Structures, 41, 1333-1344. http://doi.org/10.1617/s11527-007-9332-z

Singh, B., Kumar, A., \& Sharma, R. K. (2014). Effect of Waste Materials on Strength Characteristics of Local Clay. International Journal of Civil Engineering Research, 5(1), 61-68.

Sivapullaiah, P. V, Katageri, B., \& Herkal, R. N. (2007). Enhancement of Strength of Soft Soils with Fly Ash and Lime. In Procs. of First Sri Lankan Geotechnical Society International Conference on Soil and Rock Engineering, 6-11 August (pp. 1-6). Colombo, Sri Lanka.

Sridharan, A., \& Prakash, K. (2000). Classification procedures for expansive soils. Proceedings of ICE - Geotechnical Engineering, $143(4), 235-240$. http://doi.org/10.1680/geng.2000.143.4.235

Stoltz, G., Cuisinier, O., \& Masrouri, F. (2014). Weathering of a lime-treated clayey soil by drying and wetting cycles. Engineering Geology, 181, 281289.

Summayya, K. P., Rafeequedheen, K. M., Sameer, V. T., Khais, P. T. F., \& Jithin, K. (2016). Stabilization of Expansive Soil Treated with Tile Waste. SSRG International Journal of Civil Engineering (SSRG-IJCE), 3(3), 67-75.

Tavakoli, D., Heidari, A., \& Karimian, M. (2013). Properties of Concrete Produced with Waste Ceramic Tile Aggregate. Asian Journal of Civil Engineering, 14(3), 369-382.

Thompson, M. R. (1967). Factors influencing the plasticity and strength of lime soil mixtures. University of Illunois Bulletin, 64(100), 1-20. 
Thyagaraj, T., Rao, S. M., Sai Suresh, P., \& Salini, U. (2012). Laboratory Studies on Stabilization of an Expansive Soil by Lime Precipitation Technique. Journal of Materials in Civil Engineering, 24(8), 1067-1075. http://doi.org/10.1061/(ASCE)MT.1943-5533.0000483

Transport Research Laboratory. (2003). Literature Review:Stabilised Sub-Bases for Heavily Trafficked Roads. Retrieved from http://www.transportlinks.org/transport_links/filearea/documentstore/106_Literature Review Stabilised sub-bases.pdf

Veera Reddy, M. (2010). Investigations on stone dust and ceramic scrap as aggregate. International Journal of Civil and Structural Engineering, 1(3), 661-666.

Wattanasiriwech, D., Saiton, A., \& Wattanasiriwech, S. (2009). Paving blocks from ceramic tile production waste. Journal of Cleaner Production, 17, 1663-1668. http://doi.org/10.1016/j.jclepro.2009.08.008

Yıldız, M., \& Soğancı, A. S. (2012). Effect of freezing and thawing on strength and permeability of lime-stabilized clays. Scientia Iranica, 19(4), 10131017. http://doi.org/10.1016/j.scient.2012.06.003 